\title{
Geoscience: what remains to be discovered?
}

University of Utah, Energy \& Geoscience Institute and Department of Geology \& Geophysics, Salt Lake City, UT 84108, USA;

*Corresponding author, E-mail: rsorkhabi@egi.utah.edu

(Received: May 5, 2021; Revised accepted: July 27, 2021)

https://doi.org/10.18814/epiiugs/2021/021021

Geoscience currently faces critical challenges ranging from declining student enrollments and employment to public perception and research funding. In all these areas, geoscience is understandably competing with other fields. This article reports on the results of a 2019-2020 survey of the major questions and challenges in geoscience. The survey respondents included 136 geoscientists from various disciplines in geoscience. Altogether they suggested 370 questions which are placed under 20 broad topics and described in four categories: (1) geodynamics; (2) climate and life; (3) resources and environment; and (4) community issues (geoscientist workforce, public education and policy). Global warming and the future of the petroleum industry top the list of challenges. Prediction and mitigation of natural hazards, especially big earthquakes and explosive volcanoes, tackling environmental degradation and pollutions of various types, as well as exploration of rare earth elements and energy minerals essential to everyday life are among the practical topics of investigation. Some of the big questions pertain to the most distant geologic past - Hadean and Eo-Archean times (4.5-3.5 Ga) - during which the primitive Earth's internal structure, crust, atmosphere, oceans, and biosphere formed. Other questions concern those physical parts of the Earth - the mantle and the core - that are not directly accessible to us. Geoscience is far from integrating crustal phenomena and plate tectonics with the dynamics, heterogeneities, and evolution of the mantle. Causes of paleoclimate changes and mass extinctions and the relationships between these two remain fertile fields of research. Extraterrestrial influences such as lunar gravitational stresses, and meteorite impacts should be better integrated into earth system science. Geoscience education and workforce, public perception and support for geoscience, and the role of geoscientists in impacting policies are critical areas of attention and action.

\section{Introduction}

In 1996, John Horgan, a Scientific American journalist, published a book entitled The End of Science: Facing the Limits of Knowledge in the Twilight of the Scientific Age. Drawing on his interviews with some of the leading scientists, Horgan argued that science is coming to an end - there is not much to discover in terms of fundamental principles or big theories, both because of limitations in our tools and perception and because of significant advances science has already made. In his book, Horgan discussed the state of philosophy, physics, cosmology, biology, social science, neuroscience, and chaos theory (Horgan, 1996). Horgan's book was severely criticized by many scientists. In 1998, John Maddox, the former editor of Nature, published a book entitled What Remains to Be Discovered?, an apparent response to Horgan's book but without citing it. Maddox discussed the big questions in various disciplines of science including cosmology, physics, chemistry, biology, artificial intelligence, and mathematics; however, he ignored geoscience arguing that major questions in geology and planetary science "are all absorbing questions but no new principles are involved" (Maddox, 1998). When I first read Maddox's book, as a geoscientist, I was annoyed and felt that ignoring geoscience by a prominent science journalist was unfair and unjustified. The end of science debate in the 1990s came and went with little reaction or response from the geoscience community.

With this background, during 2019-2020 I conducted a survey of the most important questions in geoscience. The survey was conducted through emails sent out to hundreds of geoscientists and also posted through community websites of Geological Society of America (GSA), American Geophysical Union (AGU), and American Institute of Professional Geologists (AIPG). The scientists were asked to suggest (in their opinion) up to five most important questions in geoscience (including geology, geochemistry, geophysics, and applied geology, but not regional geology). A total of 136 scientists (Fig. 1) responded, and together they suggested 370 questions, many of which overlapped. I tallied these

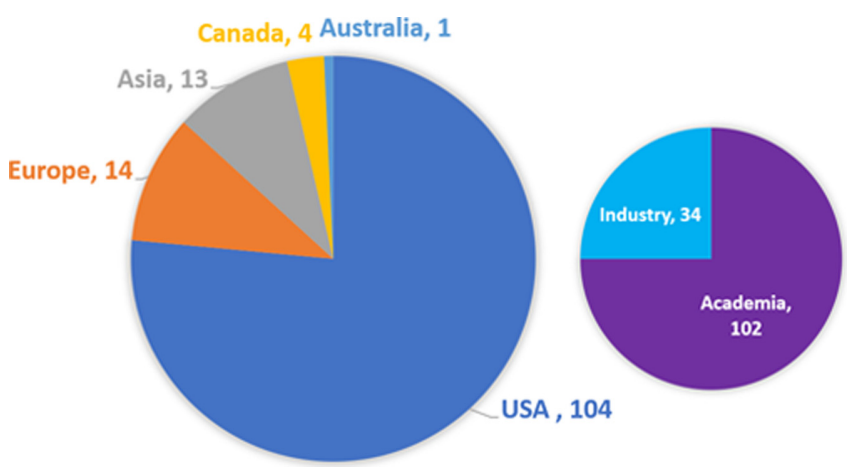

Figure 1. Distribution of survey respondents. 
responses into 20 themes, each suggested by four or more scientists. These are reported and briefly described here.

\section{Big Questions in Science: The Place of Geoscience}

From time to time, geologists have reflected on the major unresolved questions in their field. In 1889, Clarence Dutton published a (now a classic) paper entitled "On some of the greater problems of physical geology." He remarked: "The greatest problems of physical geology I esteem to be: 1st, What is the potential cause of volcanic action? $2 \mathrm{~d}$, What is the cause of the elevation and subsidence of restricted areas of the earth's surface? 3d, What is the cause of the foldings, distortions, and fractures of the strata?" (Dutton, 1889). Dutton proceeded to criticize the "contractional hypothesis" (the idea of a cooling-collapsing Earth) that was prevalent in the $19^{\text {th }}$ century to explain these phenomena. Today, we explain all these tectonic phenomena in terms of plate tectonics, but Dutton's classic paper was a milestone in our progress toward plate tectonics because it suggested the concept (and the very

\begin{tabular}{|l|}
\hline This Survey \\
\hline 1. Global Warming (40) \\
\hline 2. Petroleum Industry and Geoscience (39) \\
\hline 3. Earthquake Prediction (26) \\
\hline 4. Birth of Plate Tectonics (17) \\
\hline 5. Plate Tectonic Processes (17) \\
\hline 6. Mantle Dynamics: Plumes vs. Plates (16) \\
\hline 7. Mineral Resources (16) \\
\hline 8. Public Education and Policy (15) \\
\hline 9. Paleoclimates (13) \\
\hline 10. Natural Hazards (12) \\
\hline 11. Water Resources (11) \\
\hline 12. Mass Extinctions (10) \\
\hline 13. Energy Resources (10) \\
\hline 14. Precambrian-Cambrian Transition and \\
Cambrian Explosion (9) \\
\hline 15. Environmental Geology (7) \\
\hline 16. Origin of Life (6) \\
\hline 17. Moon-Earth Interactions (6) \\
\hline 18. Volcanic Eruptions (5) \\
\hline 19. Reversals of Earth's Magnetic Field (4) \\
\hline 20. Meteorite Impacts (4) \\
\hline
\end{tabular}

term) of "isostasy" as a mechanism of uplift and subsidence of the earth's crust.

In 1947, L. H. Adams, then president of the American Geophysical Union, gave a lecture entitled "Some unresolved problems of geophysics," and listed six major questions: (1) the origin of the mountain chains; (2) the origin of geosynclines; (3) the cause of volcanoes and other igneous activity; (4) the cause of deep earthquakes; (5) the origin of the earth's magnetic field; (6) the temperatures prevailing in the interior of the earth (Admas, 1947).

Since Dutton and Adams raised those questions, remarkable advances have been made by geoscientists around the world. Both Dutton and Adams, if they were to return today, would have been greatly impressed by these discoveries. Nevertheless, it is still important to articulate big questions and challenges in geoscience. While there are numerous questions on the minds of geoscientists and in their works, it is useful to formulate what specific questions in geoscience are significant enough to be considered as big questions of science itself. The main objective of this survey was to place geoscience in the larger context of science through the big questions and challenges that lie ahead of

\section{NSF Earth Science Big Questions}

1. How is Earth's Magnetic Field Generated?

2. When, why, and how did plate tectonics start?

3. How are critical elements distributed and cycled in the Earth?

4. What is an earthquake?

5. What drives volcanism?

6. What are the causes and consequences of topographic change?

7. How does the critical zone influence climate?

8. How does Earth's past reveal about the dynamics of the climate system?

9. How is Earth's water cycle changing?

10. How do biogeochemical cycles evolve?

11. How do geological processes influence biodiversity?

12. How can Earth science research reduce the risk and toll of geohazards?

Figure 2. Big questions and challenges in geoscience according to this survey (suggested by four or more geoscientists) compared with NASEM (National Academies of Sciences, Engineering, and Medicine, 2020) report for the National Science Foundation (NSF) Earth Sciences 2020-2030. 
geoscientists. These are categorized into 20 topics related to geodynamics (7), climate and life (6), resources and the environments (6), and community issues (1). Obviously, these do not encompass all the major geoscience questions, and the results are limited to this survey. Nevertheless, they articulate some valid points and issues facing the geoscience community. Moreover, the survey results are largely consistent with (and also more expansive than) the priority research questions for the US National Science Foundation (NSF) Earth Sciences 2020-2030, recently proposed by the American National Academies of Sciences, Engineering and Medicine (NASEM, 2020) (Fig. 2). This consistency validates the significance of these questions and challenges. Mention should also be made of Horizon Europe 2020 Program, a well-funded research initiative by the European Union to foster scientific and industrial research (until 2027) on the pressing issues of our time.

\section{Geodynamics}

\section{The Birth of Plate Tectonics}

Plate tectonics was a revolutionary discovery in the $20^{\text {th }}$ century science. It has provided a unified theory for various, seemingly unrelated, geologic phenomena from rock cycle and mountain uplifts to mineral deposits and earthquakes. However, we still do not know when, why, and how plate tectonics began in the Precambrian Earth; how our planet functioned before plate tectonics; what critical mass of conditions triggered plate tectonics; and how best we can quantify indicators to answer these questions (Condie, 2018; Cawford et al., 2018; and references therein). The significance of these questions becomes amplified when we consider that Earth is the only planet in the Solar System that enjoys active plate tectonics, and that plate tectonics has influenced every part of the planet including the biosphere (Stern, 2016). Investigating the onset and chronology of plate tectonics also involves understanding the development of the continental crust through geologic time: Was it a slow progressive growth or an early massive development (see Harrison, 2020 for details)?

\section{Plate Tectonic Processes}

Plate tectonics currently constitutes the fundamental paradigm of earth science education. Nevertheless, many aspects of plate tectonics still remain little known. Some of these questions raised in the survey were: How has plate tectonics influenced the evolution of life forms (a subject recently phrased as biogeodynamics; Zerkle, 2018)? How and when do ophiolites obduct in a convergent oceanic plate setting? What controls symmetric versus asymmetric rifting processes and how best can we image these two? What is the mechanism of low-angle normal faulting? How does a passive margin transform to an active margin and what triggers and directs the incipient subduction? How can vertical uplifts be reconciled with horizontal plate tectonics? How are some passive continental margins, intraplate basins or aulacogens (failed rift basins) rejuvenated with renewed phases of massive sedimentation? How can we clearly distinguish igneous rocks based on their geochemical signatures from various tectonic settings?

\section{Mantle Dynamics: Plumes vs. Plates}

Our geologic knowledge largely pertains to the crust accessible to us; but the crust is merely a thin skin of the global volume. Lithospheric plates are controlled by dynamic forces in the mantle, from the asthenosphere immediately below the lithosphere all the way down to the low shear velocity provinces surrounding the outer core (Davies, 2008; Khan and Deschamps, 2015). Seismic tomography and high pressuretemperature experimental mineralogy and petrology provide insights into the internal structure and composition of Earth. Isotope geochemistry and geochronology of kimberlites and ultra-deep (400-700 km) earthquakes on subducting slabs ("cold plumes") also provide valuable clues into the upper mantle. Nevertheless, the mantle remains terra incognita and thus a new frontier. Our physical access to mantle plumes is restricted to hot spot magmatism on the Earth's surface. Where do plumes rise from? How can we classify plumes, physically and compositionally, to understand processes of their formation? How can we explain triple junctions and large igneous provinces (LIPs) in terms of deep plumes vs. shallow plate tectonics? How can we study the evolution of the mantle through the geologic time as we do for the crustal rocks?

\section{Reversals of Earth's Magnetic field}

The pioneering work of Walter Elsasser in the 1940s showed that the Earth's magnetic field originates in the metallic fluid outer core. It accounts for 95 percent of the geomagnetic field at the Earth's surface and its influence reaches far beyond the solid Earth and protects life from harmful solar and cosmic radiations. In the 1950s-60s discovery of the reversals of Earth's magnetic field in the geologic past helped establish the ideas of sea-floor spreading and plate tectonics. Understanding and predicting variability in the geomagnetic field is important because these variations provide clues to the behavior and properties of the Earth's outer core, including its interactions with the lower mantle. However, we still do not know exactly how and when these reversals take place.

\section{Earthquake Prediction}

Seismology and plate tectonics have made great strides in our knowledge of earthquakes - how and where they occur. Today, a global network of seismic stations monitors and reports on earthquakes. Databases of earthquake records, paleoseismological research, mapping of seismic gaps, and probabilistic assessment of big earthquakes are all important tasks for seismologists. Nevertheless, predicting the timing of earthquakes remains a most serious problem, despite the recognition that certain physical precursors provide helpful clues (Hough, 2010). A large number of megacities are situated along the tectonically active circum-Pacific and Alpine-Himalayan belts, big earthquakes are indeed silent "time bombs" and require intense studies (Yeats, 2015). Given that Earthquake prediction is also closely associated with studies of mechanisms and patterns of crustal seismicity, not only along the active plate boundaries but also in intraplate settings. In this sense, no major earthquake should be ignored. Therefore, earthquake-prone low-income countries are in dire need of scientific contributions from the developed nations. 


\section{Volcanic Eruptions}

Volcanic eruptions are associated with earthquakes, and together they form the main tectonics hazards at active plate boundaries. In some ways, prediction of volcanic eruptions (especially their effusive phases) is easier than that of earthquakes. Volcanic eruptions pose threats to society including mudflows, acid rain, and airplane flight hazards. One fundamental question is how a volcanic eruption starts and ends, and how we can model these two conditions. Predicting the explosive activity of a volcano indeed remains a challenge. Another problem pertains to quantifying the effects of volcanic eruptions on the atmosphere and climate.

\section{Moon-Earth Interactions}

Earth's only natural satellite is a unique feature in the Solar System. Isotopic signatures indicate that the Moon resembles an early lifeless rocky Earth, and according to a widely-held hypothesis the Moon's materials were split off from Earth as a giant body, Theia, hit the proto-Earth. Whatever the mechanism for the origin of the Moon, the Earth-Moon companionship has been a long story of mutual gravitational influences. Aside from the tidal waves on Earth, we also know of moonquakes produced by Earth's gravity. Does the Moon's gravity also influence earthquakes (Ide et al., 2016) and exert tidal stresses on Earth's topography and fluid pressures in rocks? We also need a better understanding of the day-length and Earth-Moon distance over the geological time - a field of research that amazingly relies on coral paleontology, pioneered by John Wells in the 1960s.

\section{Climate and Life}

\section{Global Warming}

A large number of respondents suggested the global warming as a most critical issue of our time (IPCC, 2014; Friedlingstein et al., 2019). The complex issue involves many areas of research including in-depth understanding of climate change and carbon budget and cycle (sources and drivers as well as sinks and feedbacks), better forecasts and modeling of the impact of global warming on the environment and societies, and more importantly working out technological and policy procedures to reduce the atmospheric greenhouse gases, especially carbon dioxide emissions from fossil fuels.
PHANEROZOIC EON

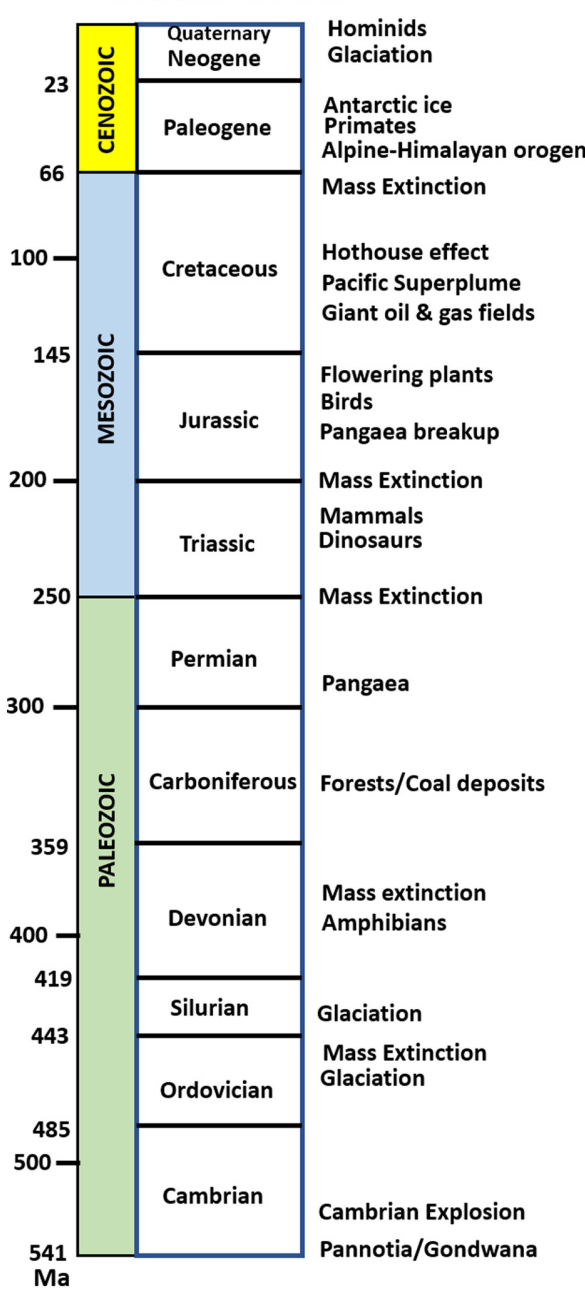

\section{PRECAMBRIAN EONS}

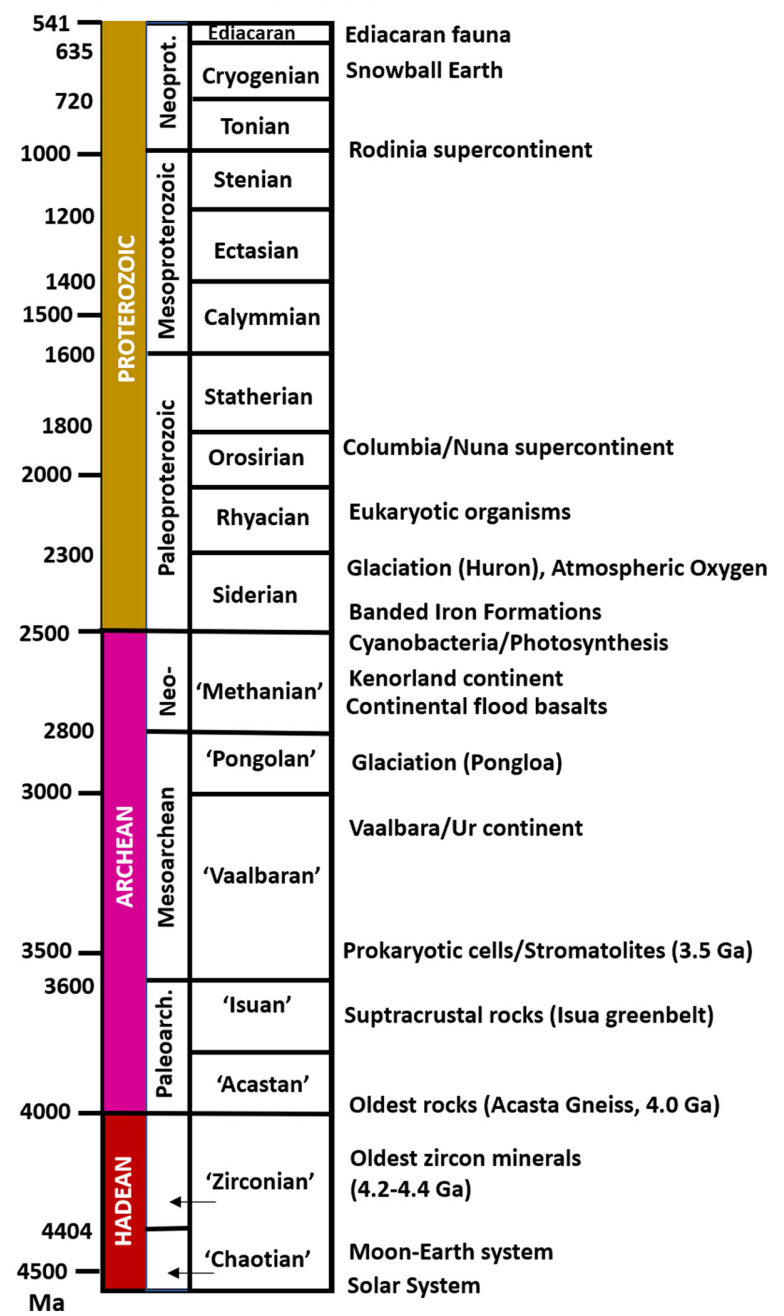

Figure 3. Some of the major tectonic, climate and evolutionary events in Earth's history. 


\section{Paleoclimates}

The recent global warning should also be considered in the context of paleoclimate history of Earth (Summerhayes, 2020). Several "hothouse" (greenhouse) periods such as those in mid-Cretaceous and Paleocene-Eocene thermal maximum require special explanations. Similarly, widespread continental glaciation is restricted to certain ages in the geologic past: Pongolan, Huron, Cryogenian (“Snowball Earth"), Late Ordovician, Silurian, Permian (Karoo), and Quaternary (Fig. 3). Studies of Earth's paleoclimates include a wide range of questions such as: What were the causes and effects of drastic variations in the atmospheric composition (especially $\mathrm{O}_{2}$ and $\mathrm{CO}_{2}$ ) over the geological time? What factors determined the onset and termination of greenhouse ("hothouse") periods and glacial ages? How did the biota respond to such drastic climate changes?

How can we resolve the chicken-and-egg relationship between climate change and variations in the atmospheric carbon dioxide? This question is particularly important for the Quaternary glacial-interglacial ages, ascribed to Milankovitch cycles, but also displayed in the see-saw pattern in the atmospheric $\mathrm{pCO}_{2}$. Another question regarding the Quaternary glacial-interglacial ages revolves around the two end member values of $\mathrm{pCO}_{2}$, roughly $180 \mathrm{ppm}$ and $280 \mathrm{ppm}$ : What regulated these limits? The current global warming should motivate a fuller understanding of the Holocene climate changes in various parts of the world, such as the Little Ice Age of Europe.

A significant improvement in paleoclimate science is to better quantify the rate of rapid paleoclimate changes by high-resolution dating of proxy records including plankton fossils, sediment cores, and ice cores.

\section{Origin of Life on Earth}

The formation of life on Earth, like other phenomena, has a naturalistic explanation. Nevertheless, how, when and where life first emerged remains a scientific mystery. Did life originate independently on Earth some four billion years ago from a "primordial organic soup" in the Earth's early oceans (as Charles Darwin, A. Oparin, J.B. Haldane and the famous Miller-Urey experiment have suggested) or were biological molecules brought to Earth from the outer space by asteroids and meteorites (as envisioned by Lord Kelvin, Svante Arrhenius, Fred Hoyle, and Francis Crick) (De Duve, 1995; Schopf, 2002)? How did the first cells with lipid membranes, replicating genetic code, and metabolic molecules emerge? In a typical chicken-or-egg relationship, was replication ("RNA world") or metabolism (proteins) the first jumping board to life? Where did the first cells emerge: In the primitive warm oceans in contact with an atmosphere free of oxygen but rich in organic molecules and subjected to lightening and ultraviolent radiation? Or in deep-sea hydrothermal vents (black smokers or white smokers) (White et al., 2020)? Were clay minerals responsible for the formation of biological molecules (the "Clay hypothesis," Cairns-Smith, 1981). Or possibly life originated in some terrestrial hydrothermal environment. The main problem is that we do not have access to the abiotic soup and its environment (abiogenesis) that produced the earliest cells. We have not been able to produce living cells, either, even though we have synthesized organic molecules and conducted genome replacement. Even if a living cell is created in the laboratory, it does not necessarily mean that the same processes created life on Earth in the first place. Nevertheless, the search for "theories of life" aids exploration of life on other planets and also deepens our understanding of survival mechanisms of microorganisms in extreme environments.

\section{Precambrian-Cambrian Transition and the Cambrian Explosion}

The Precambrian-Cambrian boundary has long been a major stratigraphic debate both in terms of a numerical date (from $600 \pm 20 \mathrm{Ma}$, first reported by Arthur Holmes in 1960, to the present value of $541 \pm 1 \mathrm{Ma}$ ) and the criteria for defining and locating this stratigraphic boundary in various parts of the world. The problem is not simply semantic. The transition from the Ediacaran to the Cambrian was indeed a time of drastic changes in the atmosphere (oxygenation), tectonics (assembly of Gondwana), and evolution (proliferation of multicellular organism or what has been dubbed as the Cambrian explosion) (Gould, 1990; Ewin and Valentine, 2013) (Fig. 3). Therefore, understanding the nature of this time interval and the inter-connected phenomena leading to the Cambrian explosion of life is an important question in the history of our planet.

\section{Mass Extinctions}

Extinction is a rule rather than an exception: at the specie level, over 99 percent of life forms have become extinct over the geologic time. In a mass extinction, a large percentage of higher taxa in several biological groups vanish within a brief interval of geologic time either due to "bad genes" (natural selection) or "bad luck" (catastrophic events) (Raup, 1991). "Five big" mass extinctions in the Late Ordovician (Ashgillian), Late Devonian (Fransnian), Late Permian (Changhsingian), Late Triassic (Rhaetian), and Late Cretaceous (Maastrichtian) have each wiped out more than two-thirds of species (Raup, 1991) (Fig. 3), although almost every stratigraphic period during the Phanerozoic is marked by at least one considerable mass extinction event (Stanley, 2016). Obviously, understanding the causes and consequences of these mass extinctions is not only a matter of curiosity, but also for our own survival. Sadly, humankind in recent decades has also been responsible for the "sixth" big mass extinction through habitat destruction, which is alarming because it harms the planet's genetic pool (aside from ethical and scientific grounds) (Kolbert, 2014).

\section{Meteorite Impacts}

There are 190 confirmed impact structures on Earth, dating from 7 years to 2.4 billion years old and they are found in all continents except for the ice-covered Antarctica (PASSC, 2020). (Antarctica, however, is a hunting ground for meteorite themselves.) All of the impact structures have been recognized since 1950 and are a very tiny portion of impact events whose records have been obliterated by erosional processes. Impact structuring as preserved on the Moon has been closely associated with the early history of planets including Earth. The disastrous consequence of extraterrestrial impacts on ecosystems is obvious although its details require in-depth studies (Grieve, 1990; Chapman and Morrison, 1989; Gehrels, 1994). At least in one popular case - the Cretaceous-Paleocene boundary - impacting seems to be 
responsible for a global mass extinction. This necessitates monitoring large asteroids or meteors approaching Earth head-on, and if necessary, destroying them or diverting their courses physically. Another question is: Do large impacts affect the Earth's surface only or do they also cause perturbations in the mantle, perhaps even as deep as the core-mantle boundary?

\section{Resources and the Environment}

\section{Petroleum Industry and Geoscience}

For nearly a century, the petroleum industry has been associated with geoscience research and universities. It has traditionally hired a large number of geology, geophysics, and engineering graduates, and has funded numerous research consortia and graduate theses, aside from research laboratories that major oil companies operated themselves. Indeed, certain fields in geoscience, such as basin analysis, micropaleontology, sequence stratigraphy, organic geochemistry, subsurface imaging, petrophysics, well logging, and seismic and other geophysical surveys, were developed and financed by the petroleum industry. Therefore, oil market crashes and oil price volatility as we witnessed during the 2020 Covid-19 pandemic (Sorkhabi, 2020) adversely affect geoscience programs in many universities. Given the worldwide movements to combat the global warming the future growth of the petroleum industry is not clear: Will the industry evolve and reinvent itself, or will it give way to other energy, mineral and environmental industries; and if the latter, will these industries be geoscienceintensive and highly supportive of research and education? These questions currently facing the geoscience community are at the heart of discussions on how to reform and develop geoscience education and research (Simmons et al., 2020).

In order for the petroleum industry to reform or re-invent itself, it has to address environmental sustainability and financial challenges. To be environment friendly and reduce its carbon footprint, the industry has to invest in the science and technology of carbon capture (for reuse or underground storage), avoid gas flaring, reduced water volume for hydraulic fracturing, and control methane emissions from shale oil and gas fields. To reduce its costs per barrel of oil production and be profitable, the petroleum industry must utilize smart data science and more efficient technologies for better subsurface imaging, locating production sweetspots, and improved recovery factors of oil and gas from reservoirs.

\section{Energy Resources}

The world (as well as the geoscience community) is facing a huge dilemma. On the one hand, the catastrophic threat of global warming (mainly from the burning of fossil fuels) is an urgent call to move toward energy sources with the least carbon footprints. On the other hand, fossil fuels currently account for 85 percent of the world's energy supply, and a rapid transition to replace the energy-dense fossil fuels will have pose formidable political, economic, and technological challenges. Added to this dilemma is the fact that global energy demand will grow (not decline) in the coming decades as the flow of affordable and abundant energy is critical to life standards of the developed world and development of low-income nations. These trends provide geoscientists with both challenges and opportunities in exploring and developing energy resources. For developing renewable energy sources and massive electrification of transportation to replace oil, exploration and production of energy minerals such as rare-earth magnetic metals for wind turbines and lithium for batteries will be crucial.

\section{Mineral Resources}

Everyday life and modern industries all depend on a vast number of minerals and elements extracted from Earth. Mineral exploration has always been at the heart of geoscience, and the field is expected to grow as global demand for minerals will increase and strategic minerals will dominate national security and geopolitics. Rare-earth metals and critical (strategic) minerals as identified by the US Geological Survey (Schulz et al., 2017) will attract particular attention and intense exploration. Improved knowledge of reserve estimates, geographic distributions, geological concentrations, and industrial recovery of critical minerals and elements will be important tasks for economic geologists.

\section{Water Resources}

Underground and surface freshwater resources used for drinking, irrigation and other residential or industrial needs constitute only one percent of the global water budget (Shiklomanov, 1993). Although water is a renewable resource, freshwater resources are unevenly distributed both seasonally and spatially, depending on terrain and climate. Geoscientists and engineers will play an important role in detailed studies of the hydrological cycle and water budget, reservoir mapping and extraction of groundwater, water resource management especially in arid environments, optimal practices of watershed modification, desalination projects, and so forth.

\section{Natural Hazards}

Natural hazards are routine geologic processes; however, their tragic impacts on human life, structures and properties have increased due to population growth and concentration in megacities prone to natural hazards as well as unpreparedness especially in developing countries. Natural hazards include a diverse set of events resulting from tectonic, hydrological, meteorological, and climatic processes, and many of them are inter-related, such as offshore earthquake-tsunami coupling. During 2000-2009, more than 7,000 geophysical disasters killed approximately1.23 million worldwide (CRED, 2020). Geoscientists and engineers can greatly contribute to studies of precise mechanisms of natural hazards, risk assessments and mapping, warning systems, mitigation, and construction of hazard-resistant structures.

\section{Environmental Geology}

Despite the obvious relationships between environmental quality and human health, rapid industrialization of the world has caused environmental pollutions of various types. Humans are now a geological force and the recent declaration of the Anthropocene age, beginning in the 1950s (Zalasiewicz et al., 2008; Ellis, 2018) is a testimony 
to our (often adverse) impacts on almost every part of the planet from the atmosphere and the oceans to landscape and forests. Global warming is a type of effect on the environmental due to pollution. Loss of biodiversity due to destruction of forests (with many species that will never come back), desertification, silent erosion of top soil (that will take centuries to recover), plastic pollution of the oceans, and so forth are tragic records of the Anthropocene. Our failure to maintain the Biosphere 2 experiment (Nelson, 2018) demonstrates how precious and irreplaceable the Earth's biosphere is, and one which we cannot afford to fail. Environmental geology is thus a great contribution of geoscientists to society, and the significance of this field and the workforce needed for its multitude tasks are expected to rise in the coming decades as human-Earth interactions will intensify even more.

\section{Community Issues}

\section{Public Education, Geoscientist Workforce, and Policy}

Most people including young children are interested to learn about minerals, fossils, life of the dinosaurs, how mountains uplift, and other geological lore. Indeed, earth science news are hugely popular (Sorkhabi, 2019). Ironically, however, Earth science is relatively underrated in our schools and K-12 education. A 2015 US survey found that only 22 states accepted an Earth and Space Science course for graduation, and only two states required a year-long Earth/Environmental Science course whereas the number of states for required Life Science and Physical Science courses for graduation were 50 and 30, respectively (Benbow and Hoover, 2015).

Crisis in geoscience education is not limited to high schools. In recent years, college enrollments in geoscience programs has decreased in the USA, UK and probably many other countries. For instance, geoscience majors in US universities decreased from 31,744 in 2016 to 25,015 in 2019 (Sucier, 2020). Meanwhile, the US Bureau of Labor projects a five percent growth for geoscientist jobs from 2019 to 2029 , faster than many other occupations. This growth is needed in energy, environment, and resource sectors (US Bureau of Labor Statistics, 2020).

From education to employment and funding, geoscience is competing with other fields such as bioscience, nanoscience, artificial intelligence, and business management. How can we communicate the value of geoscience to the public, school boards, and policy makers? This is a crucial challenge for the geoscience community; it is also a task that only geoscientists should perform. In introducing geoscience to the public and students it is important to present it not as an isolated dry science but a broad field that uses and integrates all sciences to study Earth. We should also present a new public image of the geologist beyond one who mainly digs for fossil fuels and loves earthquake incidents.

\section{Final Remarks}

Geoscience, like any other science, progresses by addressing big questions and unresolved problems, both theoretically and methodologically. The above-mentioned issues are only a selection of major geoscience questions limited to this survey. Nevertheless, articulating the big questions, even partially, has several benefits. Firstly, it helps to identify our knowledge gaps, research priorities, and pathways to advance geoscience. Secondly, it helps us better understand the interactive nature of Earth and how the study of a single problem often requires several disciplines and methods. This, in turn, motivates the entire community to interact, communicate, and go beyond geographic and cultural barriers (for instance, between geologists, geophysicists, and engineers), and unites the geoscience community along collaborative plans of action. Thirdly, it helps to restructure and improve geoscience education in universities in order to train the future generations of scientists required to tackle these issues. And finally, the geoscientist community becomes more aware of how to relate their research work to the needs of society and contribute to policies that positively impact the environment, security, economy, and wellness.

Some of the questions and challenges in geoscience pertain to basic research, while others are directly related to applied science and technology. Many of the big questions in geoscience are multidisciplinary and require various perspectives and methods including geological, geochemical, geophysical and modeling. Moreover, given that geoscience has over two centuries of research legacy and knowledge base, applications of big data science, artificial intelligence, and machine learning will advance the synthesis and analysis of data on a global scale. In the end, geoscience is essentially a science of discovery and exploration, whether of processes and rock records or of resources and hazards. And in all these endeavors, observation, fieldwork, mapping and visualization play key roles.

Science is an endless frontier. Big questions in science are somewhat subjective and depend on the questioner. Questions like what was there before the big bang or what happens inside a black hole are not in the scope of geoscience. However, for geoscientists, understanding the evolution and operation of our one and only planet and providing the humanity with vital resources and a safe environment are of utmost importance.

\section{Acknowledgments}

I am grateful to all survey respondents for their suggestions, comments, and feedback. Gratitude also to GSA, AGU, and AIPG for offering valuable community forums which were utilized in this survey, and to the anonymous reviewers of the Episodes. I alone, however, am responsible for any error.

\section{References}

Adams, L.H., 1947, Some unresolved problems of geophysics. Transactions of the American Geophysical Union, v. 28, pp. 673-679.

Benbow, A., and Hoover, M., 2015, Earth and Space Sciences Education in the U.S. Secondary Schools: Key Indicators and Trends. American Geoscience Institute, Alexandria, Virginia, $10 \mathrm{p}$.

Cairn-Smith, A.G., 1982, Genetic Takeover and the Mineral Origins of Life. Cambridge University Press.

Cawford, P.A., Hawkesworth, C.J., Pisarevsky, S.A., Dhuime, B., Capitanio, F.A., and Nebel, O., 2018, Geological archive of the onset of plate tectonics. Philosophical Transactions Royal Society, v. A376, 21170405.

Condie, K.C., 2018, A planet in transition: the onset of plate tectonics 
between 3 and 2 Ga?. Geoscience Frontiers, v. 9, pp. 51-60.

CRED (Center for Research on the Epidemiology of Disasters), 2020, Human Cost of Disaster (2000-2019): CRED Crunch No. 61 (Dec. 2020), Université catholique de Louvain, Brussels, Belgium. Online: https:// cred.be/sites/default/files/CRED-Disaster-ReportHuman-Cost2000-2019.pdf

Davies, G.F., 2008, Dynamic Earth: Plates, Plumes and Mantle Convention. Cambridge University Press, Cambridge, $470 \mathrm{p}$.

De Duve, Ch., 1995, Vital Dust: The Origin and Evolution of Life on Earth. Basic Books, New York, 362 p.

Dutton C.E., 1889. On some problems of the greater problems of physical geology. Philosophical Society of Washington Bulletin, v. 12, pp. 51-64.

Ellis, E.C., 2018, Anthropocene: A Very Short Introduction. Oxford University Press, Oxford, $208 \mathrm{p}$.

Erwin, D., and Valentine, J., 2013, The Cambrian Explosion: The Construction of Animal Biodiversity. W. H. Freeman, New York, 416 p.

Friedlingstein, P., and 75 others, 2010. Global carbon budget 2019. Earth System Science Data, v. 1, pp. 1783-1838, doi.org/10.5194/essd-111783-2019.

Gehrels, T. (Eds.), 1994, Hazards due to Comets and Asteroids. University of Arizona Press, Tucson, $1300 \mathrm{p}$.

Gould, S.J., 1990, Wonderful Life: The Burgess Shale and the Nature of History. W.W. Norton, New York, $352 \mathrm{p}$.

Grieve, R.A.F., 1990, Impact cratering on the Earth. Scientific American, v. 262 , pp. 66-73.

Harrison, T.M., 2020, Hadean Earth. Springer Nature Switzerland, 380 p.

Horgan, J., 1996. The End of Science: Facing the Limits of Knowledge in the Twilight of the Scientific Age. Broadway Books, New York, 320 p.

Hough, S.E., 2010. Predicting the Unpredictable: The Tumultuous Science of Earthquake Prediction. Princeton University Press, Princeton, $272 \mathrm{p}$.

Ide, S., Yabe, S. and Tanaka, Y., 2016, Earthquake potential revealed by tidal influence on earthquake size-frequency statistics. Nature Geoscience, v. 9 , pp. 834-837.

IPCC (Intergovernmental Panel on Climate Change), 2014, Fifth Assessment Report. Online: https://www.ipcc.ch/report/ar5/syr/

Khan, A., and Deschamps, F. (Eds.), 2015, The Earth's Heterogenous Mantle: A Geophysical, Geodynamical, and Geochemical Perspective. Springer Nature, Switzerland, $545 \mathrm{p}$.

Kolbert, E., 2014, The Sixth Extinction: An Unnatural History. Henry Holt, New York, $336 \mathrm{p}$.

Maddox, J., 1998, What Remains to Be Discovered? Meeting the Secrets of the Universe, the Origins of Life, and the Future of Human Race. Simon \& Schuster, New York, 448 p.

NASEM (National Academies of Sciences, Engineering, and Medicine), 2020, A Vision for NSF Earth Sciences 2020-2030: Earth in Time. The
National Academies Press, Washington D.C., 130 p.

Nelson, M, 2018, Pushing Our Limits: Insights from Biosphere 2. University of Arizona Press, Tucson, $328 \mathrm{p}$.

PASSC (The Planetary and Space Science Centre) 2020, Earth Impact Database: http://www.passc.net/EarthImpactDatabase/New\%20website_05-2018/Index.html

Raup, M.D., 1991, Extinction: Bad Genes or Bad Luck?: W.W. Norton, New York, $230 \mathrm{p}$.

Saucier, H., 2020, Geoscience programs evolve through declining enrollment. AAPG Explorer, v. 41, pp. 10-13.

Schopf, W. (Eds.), 2002, Life's Origins: The Beginnings of Biological Evolution. University of California Press, Berkley, $224 \mathrm{p}$.

Schulz, K.J, DeYoung, J.H., Seal, R.S., and Bradley, D.C. (Eds.), 2017, Critical mineral resources of the United States - Economic and environmental geology and prospects for future supply. USGS Professional Paper 1802, $862 \mathrm{p}$.

Shiklomanov, I., 1993, World fresh water resources. In: Gleick, P.H. (Eds.) Water in Crisis: A Guide to the World's Fresh Water Resources. Oxford University Press, New York, $540 \mathrm{p}$.

Simmons, M., Davies, A., Hill, A.W., and Stephenson, M., 2020, Who needs geoscientists?. GeoExpro, v. 17, pp. 14-18.

Sorkhabi, R., 2019, Earth science is most popular with the public. The Professional Geologist, v. 58, pp. 44-45.

Sorkhabi, R., 2020, How will the 2020 oil crisis end? First Break, v. 38, pp. 31-34.

Stanley, S.M., 2016, Estimates of the magnitude of major marine mass extinctions in earth history. PNAS, v. 113, (18 October, 2016). www. pnas.org/cgi/doi/10.1073/pnas.1613094113

Stern, R.J., 2016, Is plate tectonics needed to evolve technological species on exoplanets? Geoscience Frontiers, v. 7, pp. 573-580.

Summerhayes, C.P., 2020. Paleoclimatology: Form Snowball Earth to the Anthropocene. Wiley-Blackwell, Oxford, $560 \mathrm{p}$.

US Bureau of Labor Statistics, 2020, Occupational Outlook Handbook: Geoscientists. Online: https://www.bls.gov/ooh/life-physical-and-socialscience/geoscientists.htm

White, L., and 9 others, 2020, Simulating Serpentinization as It Could Apply to the Emergence of Life Using the JPL Hydrothermal Reactor. Astrobiology, v. 20, pp. 307-326.

Yeats, R., 2015, Earthquake Time Bombs. Cambridge University Press, Cambridge, $361 \mathrm{p}$.

Zalasiewicz, J., et al., 2018, Are we now living in the Anthropocene. GSA Today, v.18, doi: 10.1130/GSAT01802A.1

Zerkle, A., 2018, Biogeodynamics: bridging the gap between surface and deep Earth processes. Philosophical Transactions Royal Society, v. A376, (Nov. 2018), 20170401.

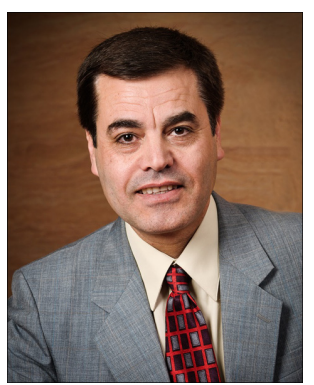

Rasoul Sorkhabi, Ph.D. is a research professor at the University of Utah's Energy \& Geoscience Institute and Department of Geology \& Geophysics, Salt Lake City, USA. He is a member of GSA, AGU, AAPG, and AIPG. His research has ranged from the tectonics and geochronology of the Himalaya to fault-fluid flow in deepwater turbidites. He has co-edited GSA Special Paper 330 (1999), AAPG Memoir 85 (2005), Tectonophysics vol. 451 (2008), GSA Special Paper 525 (2017), and GSL Special Publication 465 (2019). 